\title{
Ritual di Bawah Pohon Asam Mbah Gosang di Pasar Peterongan Semarang
}

\author{
Siti Nur Asiyah, ${ }^{1}$ Mudjahirin Thohir, Af'idatul Lathifah \\ Program Studi Antropologi, Fakultas Ilmu Budaya, Universitas Diponegoro \\ Jalan Prof Soedharto, SH. Tembalang Semarang 50275
}

\begin{abstract}
Along with the development of modern times, society maintains its tradition as a unique cultural identity, including the phenomenon of rituals that take place under a large tamarind tree which is believed to be the firing of a sacred figure named Mbah Gosang, located in the middle of an urban area, precisely at Peterongan Semarang Market. The focus of the discussion which is the main objective of this research is to interpret the ritual meanings express in the ritual implementation. This research uses the theory of symbolic interactionism in explaining ritual phenomena, which in implication refers to social actions carried out by individuals in representing cultural meanings and symbols around them. The method used in this study is in the form of ethnographic methods, while the source of research data is obtained from participatory observation, in-depth interviews, and literature review. The informants consisted of the caretaker and Mbah Gosang pilgrim who had been directly involved in the implementation of ritual traditions. Based on the results of the study, the phenomenon of rituals carried out under the Mbah Gosang tamarind tree has two forms of cultural traditions in the form of a pilgrimage ritual and suronan ritual which in essence involves Mbah Gosang as an intermediary for prayer or tawassul to God. The series of ritual processions has their own symbolic meaning. Generally, people who carry out these rituals have the motivation to improve the economy, look for prosperity in life, and look for clues in dealing with life problems. The function of the ritual itself is as a form of respect for ancestors, cultural inheritance, forms of effort, reminders of death, and means of social integration, while the purpose of the ritual is to draw closer to God Almighty.
\end{abstract}

Keywords: Ritual, Mbah Gosang tamarind tree, pilgrims, blessing

\section{Pendahuluan}

Perkembangan peradaban manusia semakin maju seiring dengan bergulirnya zaman modern seperti sekarang ini. Perkembangan teknologi dan ilmu pengetahuan manusia yang terdapat di kotakota besar misalnya menyebabkan pola pikirnya juga ikut berkembang dari yang mulanya tradisional menjadi modern. Salah satu ciri-ciri manusia modern adalah kecenderungan berfikir sistematis dan kritis terhadap segala sesuatu yang berada di sekitar mereka. Tanpa disadari, di tengah hiruk pikuk kemoderanan kota tersebut, ternyata masih ada beberapa kelompok orang yang masih percaya kepada benda yang dianggap memiliki kekuatan ghaib di baliknya, misalnya

${ }^{1}$ Penulis Korespondensi

Email: nurasiyahs664@gmail.com

Ritual di Bawah Pohon Asam Mbah Gosang di Pasar Peterongan Semarang

Siti Nur Asiyah, ${ }^{1}$ Mudjahirin Thohir, Af'idatul Lathifah 
fenomena budaya yang terjadi di Pasar Peterongan Semarang, ada sebuah pohon asam berusia tua, oleh beberapa masyarakat sangat disakralkan. Warga sekitar meyakini bahwa pohon asam besar itu ditunggu oleh seorang tokoh yang bernama Mbah Gosang. Menurut Winarsih (2008: 29), banyak orang yang meminta petunjuk pada Mbah Gosang yang menurut keyakinan masyarakat, khususnya masyarakat Peterongan dan Wonodri, memiliki daya linuwih ${ }^{2}$ dan merupakan sosok yang mengayomi mereka", benarkah? Inilah yang menggugah penulis untuk mengkajinya.

Pasar menjadi bagian penting dari kehidupan masyarakat dalam pemenuhan kebutuhan sehari-hari. "Pasar adalah tempat yang mempunyai unsur-unsur sosial, ekonomi, kebudayaan, politis, dan lain-lainnya, tempat pembeli dan penjual (atau penukar tipe lain) saling bertemu untuk mengadakan tukar menukar" (Belshaw, 1981: 10). Fenomena pasar tidak hanya dapat dilihat dari sisi ekonomi saja, melainkan juga dapat ditelisik lebih dalam lagi melalui unsur budaya yang terkandung di dalamnya. Pasar Peterongan selain mempunyai peran sebagai tempat berlangsungnya perputaran ekonomi dan aktivitas tawar-menawar, pasar ini juga mempunyai peran sebagai tempat berlangsungnya tradisi yang terus dijaga kelestarian dan kesakralannya oleh masyarakat sekitar. Pohon asam Mbah Gosang merupakan sebuah simbol yang menjadi saksi sejarah berdirinya Pasar Peterongan dan peradaban manusia yang ada di Kota Semarang ini, yang dihormati oleh masyarakat sekitar. Tidak semua masyarakat paham terhadap simbol tradisi yang ada di sekitar mereka, khususnya mengenai tradisi yang ada di Pasar Peterongan. Perlu adanya pengungkapan simbolsimbol tradisi yang masih tenggelam dengan hiruk-pikuk ekonomi pasar. Suatu sistem nilai-budaya terdiri dari konsepsi-konsepsi, yang hidup dalam alam pikiran sebagian besar warga masyarakat, mengenai hal-hal yang harus mereka anggap amat bernilai dalam hidup (Koentjaraningrat, 1984: 25).

Ada beberapa penelitian sebelumnya yang membahas mengenai ritual. Pertama, penelitian Clifford Geertz antara tahun 1960-1970 yang berjudul Kebudayaan dan Agama, dalam tulisannya tersebut, dijelaskan bagaimana agama berlaku sebagai sebuah sistem kebudayaan, serta analisis simbol-simbol sakral yang ada dijelaskan dalam berbagai ritus dan kebudayaan, terkhusus di Jawa. Kedua, penelitian yang dilakukan oleh Nur Syam (2005) dalam bukunya yang berjudul Islam Pesisir yang membahas tentang pemahaman terhadap tradisi Islam lokal yang berkembang di daerah pesisiran sehingga muncul berbagai ritus upacara yang dilakukan oleh masyarakat pesisir, yang berimplikasi terhadap penggolongan sosial dalam hal religio-kultural dan atau religio-politik. Ketiga, penelitian yang dilakukan oleh Ayatullah Humaeni (2015) dalam sebuah jurnal yang berjudul Ritual, Kepercayaan Lokal dan Identitas Budaya Masyarakat Ciomas Banten yang mengkaji sistem kepercayaan lokal, karakteristik dan identitas kultural masyarakat, serta ritual sosial keagamaan masyarakat Ciomas. Keempat, penelitian yang dilakukan oleh Tri Winarsih (2008) dalam skripsinya yang berjudul Perkembangan dan Peranan Pasar Peterongan di Semarang terhadap Kehidupan Sosial-Ekonomi Masyarakat di Kelurahan Peterongan dan Sekitarnya Tahun 1978-2001. Penelitian tersebut mengangkat fokus kajian sejarah pasar peterongan dan perkembangan yang terjadi pada Pasar Peterongan antara tahun 1978-2001. Perbedaan penelitian ini dengan penelitian-penelitian yang sebelumnya, terletak pada ruang lingkup kajian kualitatifetnografi yang mencoba menafsirkan simbol-simbol ritual yang berlangsung di bawah pohon asam Mbah Gosang, sedangkan pada penelitian sebelumnya belum ada kajian etnografis yang secara khusus membahas mengenai ritual yang terjadi di bawah pohon asam Mbah Gosang yang berlokasi di Pasar Peterongan Semarang.

\footnotetext{
2 Daya linuwih adalah suatu bentuk energi tidak kasat mata yang berhubungan dengan dunia supranatural, biasanya memiliki kekuatan melampaui daya dan nalar manusia pada umumnya.
} 
Lokasi penelitian ini berada di Pasar Peterongan Semarang, merupakan salah satu pasar tradisional di Semarang yang terletak di Jalan MT. Haryono No. 936 Kota Semarang. Pemilihan lokasi ini didasarkan pada keunikan Pasar Peterongan yang tidak hanya menjadi tempat berlangsungnya kegiatan ekonomi, namun pasar ini juga turut menjadi tempat pelaksanaan budaya masyarakat tradisional berupa tradisi ritual yang berlangsung di bawah pohon asam Mbah Gosang. Pohon asam Mbah Gosang ini terletak persis di pelataran Pasar Peterongan, berhadapan langsung dengan Jalan Raya MT. Haryono. Menurut cerita yang berkembang di masyarakat, tradisi ritual tersebut mengandung fenomena magis terkait hal-hal kepercayaan yang berhubungan dengan pohon asam Mbah Gosang. Urgensi dari penelitian ini yaitu untuk mengetahui kebenaran tradisi yang ada, serta untuk menafsirkan secara kultural terkait keberadaan budaya ritual yang dilaksanakan di bawah pohon asam Mbah Gosang, dan ditambah lagi dengan munculnya asumsi bahwa ritual yang dilaksanakan di bawah pohon asam Mbah Gosang tersebut merupakan bentuk dari perbuatan syirik sehingga harus dilakukan kajian lebih lanjut mengenai fenomena yang sebenarnya terjadi di lapangan, terlepas dari kesimpang-siuran cerita tradisi dan asumsi-asumsi pikiran yang berkembang di masyarakat.

\section{Metode Penelitian}

Penelitian ini menggunakan metode penelitian etnografi. Etnografi sendiri secara harfiah berarti tulisan atau laporan tentang suatu suku bangsa yang ditulis oleh seorang antropolog atas hasil penelitian lapangan selama berbulan-bulan atau bertahun-tahun lamanya (Spradley, 1997). Seorang etnografer tidak dapat melepaskan perhatian mereka dari manusia, tingkah laku, adat, dan emosi. Mereka tidak hanya melihat fenomena yang terjadi, tetapi juga memahami makna di balik fenomena tersebut. Sudut pandang penelitian etnografi dapat berbeda dan memiliki keunikan tersendiri dari penelitian lain, jika penelitian sosial lain yang melihat suatu peristiwa dari sudut pandang penelitinya (etik) maka cara pandang yang dipakai dalam penelitian etnografi dilihat dari sudut pandang subjek informan ${ }^{3}$ yang diteliti (emik).

Metode pengumpulan data yang digunakan adalah kajian pustaka, observasi terlibat, dan wawancara mendalam. Sedangkan dalam menganalisis data, peneliti menggunakan teknik analisis data deskriptif dalam menjelaskan setiap fenomena penelitian yang ada. Analisis data deskriptif digunakan untuk menggambarkan atau mendeskripsikan secara menyeluruh mengenai karakteristik kultural yang dapat mempengaruhi tindakan sosial individu.

\section{Hasil \& Pembahasan}

\subsection{Makna Ritual Di Bawah Pohon Asam Mbah Gosang}

Ritual yang dilakukan di bawah pohon asam Mbah Gosang, yakni berupa ritual ziarah di punden Mbah Gosang pada hari-hari biasa, dan puncaknya pada ritual suronan yang mengadopsi tradisi slametan yang dilaksanakan pada tanggal 10 Suro. Kedua ritual ini dipegang oleh seorang juru kunci pilihan yang dipercaya untuk menjaga punden dan pohon asam Mbah Gosang sebagai tempat sakral yang memerlukan perlakuan-perlakuan khusus dalam merawatnya, masyarakat menyebutnya dengan juru kunci Mbah Gosang. Juru kunci Mbah Gosang saat ini bernama Pak

${ }^{3}$ Semua nama informan dalam penelitian ini akan disamarkan untuk melindungi kepentingan privasi informan. 
Marno (49 tahun), ia baru menjabat kurang lebih satu tahun. Juru kunci sebelumnya bernama Mbah Wagiman (60 tahun), ia sudah berpengalaman menjabat sebagai juru kunci Mbah Gosang selama sembilan tahun lamanya dan sampai sekarang ia masih tinggal di dekat punden Mbah Gosang. Ritual dalam penelitian ini memiliki tata cara yang unik dalam memadukan sistem kepercayaan suku Jawa dengan kepercayaan agama Islam, atau yang disebut dengan istilah Islam Kejawen. Kejawen di sini berperan sebagai tradisi sekaligus kepercayaan yang memiliki nilai-nilai religius, sakral, serta memiliki sugesti keagamaan.

Kelakuan keagamaan selalu lekat dengan emosi keagamaan atau getaran jiwa yang mendorong manusia untuk senantiasa melakukan tindakan-tindakan yang berkaitan dengan religi, seperti halnya dengan upacara keagamaan (rites). Koentjaraningrat (1985) mengataan bahwa, dalam suatu ritus dan upacara religi terdapat lima komponen di dalamnya, yakni berupa (1) emosi keagamaan; (2) sistem keyakinan; (3) sistem ritus dan upacara; (4) peralatan ritus dan upacara; dan (5) umat agama. Kelima komponen religi tersebut mempunyai hubungan fungsi yang erat satu sama lain yang saling mempengaruhi.

\subsection{Sistem Keyakinan}

Tempat berlangsungnya suatu ritual identik dengan tempat yang dikeramatkan, yakni tempat di mana roh nenek moyang bersemayam. Pohon asam besar dan punden Mbah Gosang yang berada di depan Pasar Peterongan sendiri merupakan bentuk dari properti penanda zona sakral di Pasar Peterongan yang merepresentasikan bahwa dalam kawasan tersebut terdapat kekuatan lain yang menjaga dan berhak menguasai atas tempat itu, yaitu roh nenek moyang warga Peterongan yang bernama Mbah Gosang. Dasar pemikiran tersebut kemudian membuat masyarakat untuk melakukan tindakan-tindakan spiritual tertentu di tempat itu untuk menghormati, bersilaturahmi, ataupun melibatkan nenek moyang mereka dalam setiap bagian kehidupan mereka.

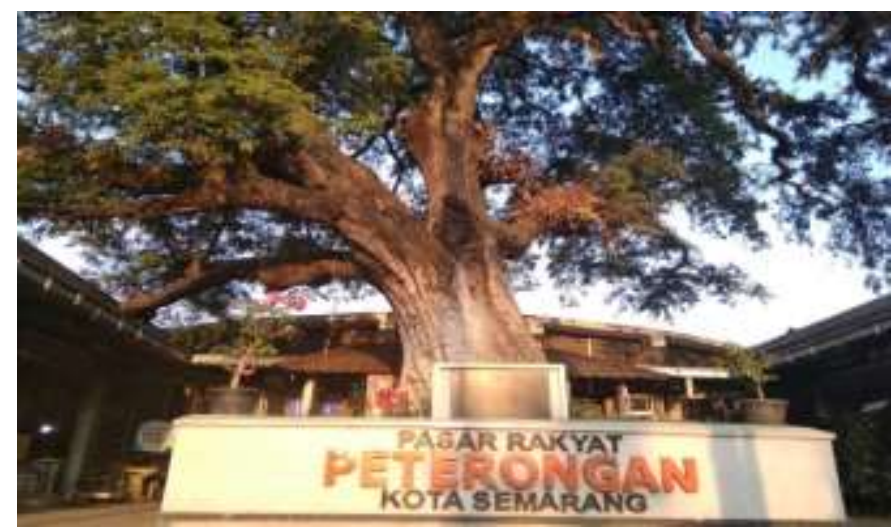

Gambar 1. Pohon Asam Mbah Gosang

Keyakinan masyarakat terhadap adanya kekuatan Mbah Gosang yang menguasai kawasan punden dan pohon asam besar di depannya tersebut bukan tanpa dasar, terdapat pengalamanpengalaman magis yang telah dialami baik oleh masyarakat terkait aktivitas yang berhubungan dengan kedua tempat tersebut, maupun oleh juru kunci Mbah Gosang yang merupakan seorang yang dipercaya untuk menjaga tempat-tempat sakral yang berhubungan dengan Mbah Gosang. Menurut seorang Sejarawan Semarang, Djawahir Muhammad (1996), syahdan pada tahun 1964 diadakan sayembara bagi siapapun yang bersedia menebang pohon asam itu akan diberikan sejumlah hadiah. 
Singkat cerita ada seorang kiai dari kampung Pleburan yang berani mengambil resiko itu, akan tetapi saat baru berhasil memotong sebagian dahan dan rantingnya, mendadak beliau jatuh sakit, dan selang beberapa waktu kemudian meninggal dunia.

Menurut penuturan Mbah Wagiman ada beberapa pengalaman magis yang tidak bisa dinalar sewaktu ia masih menjabat sebagai juru kunci dulu, tepatnya sebelum punden Mbah Gosang mengalami pemugaran. Ia bercerita dengan santai di sebuah bangku serambi kepada beberapa orang yang sedang duduk-duduk di sana. Tujuh tahun lalu sekitar tahun 2012, saat itu ada seorang orang gila yang selalu mengikuti kemana pun Mbah Wagiman pergi selama tiga bulan lamanya. Singkat cerita setelah mengikuti Mbah Wagiman masuk ke dalam punden Mbah Gosang, orang gila tersebut tiba-tiba keluar dengan kondisi mental yang normal, sembuh seperti sedia kala. Anehnya saat orang gila yang lain mencoba mengikuti jejak orang gila pertama tadi yang mendapatkan kesembuhan di punden Mbah Gosang, tetapi cara tersebut tersebut tidak dapat berhasil. Hal tersebut dapat saja terjadi karena memang terkadang tata cara ritual dan perlakuan proses kesembuhan seseorang itu berbeda-beda, tidak dapat disamakan antara satu orang dengan orang lainnya.

Kemagisan lain terkait dengan kekuatan supranatural yang dimiliki Mbah Gosang juga menyertai pada saat dilakukannya pembangunan Pasar Peterongan dan sekaligus pembangunan punden beberapa tahun lalu yang berlangsung pada tahun 2015-2016. Sebelum dilakukan pembongkaran punden, dari pihak pemborong dan dinas pasar meminta Mbah Wagiman untuk memintakan ijin kepada Mbah Gosang supaya nantinya dalam proses pembangunannya aman dari segala gangguan. Akhirnya kemudian dimintakanlah izin kepada Mbah Gosang terkait akan adanya pembangunan kembali pasar dan punden tersebut, permintaan tersebut diizinkan oleh Mbah Gosang namun dengan syarat tidak boleh merusak apa pun yang menjadi tempat keberadaan Mbah Gosang, yakni pohon asam tersebut. Tidak disangka-sangka, ternyata pada saat proses pembangunan ada satu pekerja yang memotong sedikit dahan dari pohon asam tersebut karena menghalangi proses pengerjaan bangunan pasar. Baru sampai pada dua tebangan dahan pohon, tiba-tiba pekerja tersebut langsung terjatuh dengan sekitar ketinggian kurang lebih 0,5 meter. Pekerja tersebut kemudian langsung dibawa ke pulang ke rumah, namun setelah beberapa hari kemudian terdengar kabar bahwa pekerja tersebut akhirnya meninggal.

Kekuatan spiritual yang menyelimuti kesakralan pohon asam dan punden Mbah Gosang pada dasarnya masih dipercaya sampai sekarang, namun tidak sebanyak seperti dulu. Ramai atau sepinya peziarah tidak dapat ditentukan, tergantung hajad dari masing-masing orang yang ingin kesana. Orang-orang sekarang lebih banyak yang berpikir secara rasional terlepas dari kepercayaan tradisional yang bersifat irasional, pun kharisma kesakralan dari pohon asam dan punden Mbah Gosang yang sekarang sudah mulai pudar sejak punden tersebut mengalami rekonstruksi bangunan yang bersifat terbuka sehingga siapa pun bisa melihat secara langsung aktivitas yang berlangsung di dalam punden.

Para peziarah Mbah Gosang, seperti halnya kelima informan yang penulis temui mempunyai kebiasaan melakukan ritual ziarah ketika dihadapkan dengan hajad-hajad tertentu yang ingin dicapai. Pada umumnya, mereka mengetahui adanya pepunden Mbah Gosang berasal dari anggota keluarga khususnya orang tua, lingkungan tempat tinggal, dan lingkungan tempat bermain.

Berdasarkan dari lima informan yang ditemui oleh penulis, rata-rata orang yang datang ke Mbah Gosang tersebut mempunyai motivasi yang beragam, di antaranya, yaitu (1) perbaikan ekonomi, (2) kemakmuran hidup; mencakup perlindungan, dagangan agar laris, kesembuhan penyakit, dan kelancaran karier, (3) mencari petunjuk dalam menghadapi masalah kehidupan. Begitu pula dengan asal-usulnya, ada warga lokal Semarang dan ada pula warga luar Semarang yang merupakan warga asli Solo. 
Menurut pekerjaannya, lima orang informan ini terdiri dari empat kelompok latar belakang pekerjaan yang berbeda, yakni juru parkir, pedagang, driver ojek online (ojol), dan pegawai swasta. Latar belakang pekerjaan yang berbeda tersebut ternyata memunculkan kepentingan maksud ziarah yang berbeda pula, antara lain: Mbah Yono yang bekerja sebagai juru parkir pasar memiliki maksud ziarah untuk memperbaiki perekonomiannya; kemudian Bu Ani dan Mbah Karni yang berkerja sebagai pedagang memiliki tujuan untuk mencapai kemakmuran hidup, misalnya pada Bu Ani maksud dari kemakmuran hidupnya adalah mencari perlindungan hidup dan agar dagangan laris, sedangkan Mbah Karni maksud dari kemakmuran hidupnya adalah berupa kesembuhan penyakit dan kelancaran karier keluarganya; lalu Mas Norman yang berekrja sebagai driver ojol dan Mas Parto yang bekerja sebagai pegawai swasta, keduanya memiliki maksud ziarah yang sama yaitu untuk mencari petunjuk dalam menghadapi masalah kehidupan.

Menurut Irianto (2015), agen atau individu-individu menggunakan habitus (kebiasaan) dalam merespon realitas sosial, yang mana habitus merupakan interpretasi tersirat yang bersumber dari pengalaman-pengalaman individu berhubungan dengan individu lain dalam ruang sosial. Kepercayaan para peziarah terhadap ritual yang dilakukan di punden Mbah Gosang ini tentunya dengan alasan yang patut dihargai. Alasan tersebut bisa berasal dari fakta-fakta sosial yang ada kaitannya dengan Mbah Gosang yang berkembang di lingkungan mereka atau bahkan dari pengalaman magis yang telah mereka alami sendiri selama melakukan ritual ziarah Mbah Gosang.

\subsection{Simbolisme Ritual Ziarah Mbah Gosang}

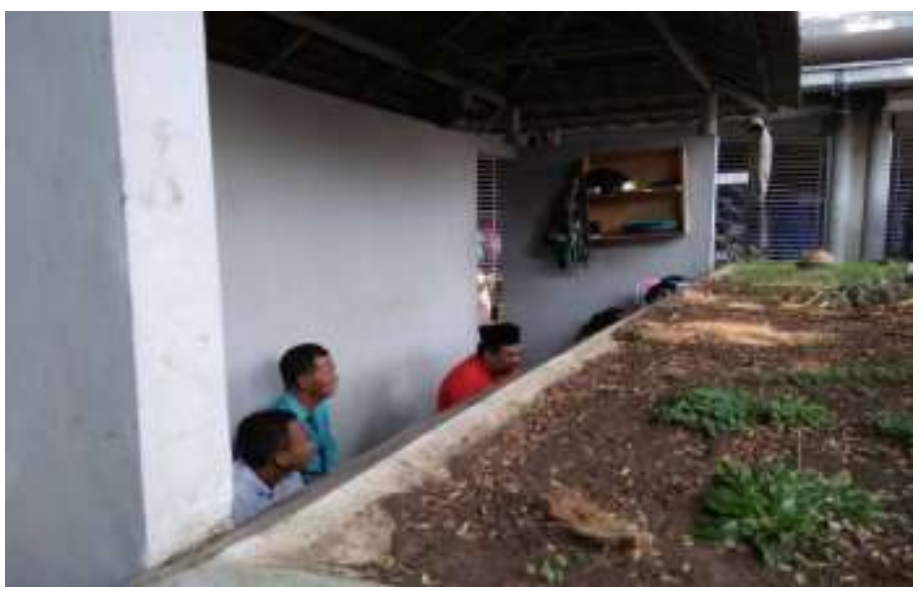

\section{Gambar 2. Punden Mbah Gosang menjadi Tempat Ziarah}

Ziarah Mbah Gosang hampir sama dengan ziarah yang dilakukan terhadap wali-wali Allah, yakni dengan bertawassul atau memohon doa kepada Allah dengan perantara melalui tokoh-tokoh pemuka Islam yang dianggap suci dan dekat dengan Allah, tujuannya adalah satu, yaitu agar mendapatkan berkah dari wali tersebut. Penghormatan masyarakat terhadap Mbah Gosang, didasarkan pada keyakinan masyarakat bahwa Mbah Gosang merupakan tokoh suci yang mempunyai pengaruh besar terhadap kehidupan masyarakat Peterongan sehingga setelah kepergiannya pun ia masih dihormati keberadaannya pada petilasan yang dulu sempat ia singgahi.

Petilasan yang berada di sekitar pohon asam besar tersebut kemudian sampai sekarang menjadi tempat ziarah, orang-orang yang berdoa di sana menjadikan Mbah Gosang sebagai perantara doa kepada Tuhan agar mendapatkan berkah berupa nasib baik, keselamatan, perlindungan, ketenangan, kelapangan rizki, dan lain sebagainya. Orang yang tidak tahu betul 
mengenai penafsiran ziarah Mbah Gosang akan menganggap sepintas ritual tersebut adalah hal yang bersifat musyrik. Sebenarnya ziarah Mbah Gosang pada dasarnya merupakan bentuk tawassul dari ajaran Islam. Tawassul dalam Islam merupakan sesuatu yang diperbolehkan, namun pada pratiknya sering terjadi penyalahartian ataupun penyalahgunaan wasilah atau suatu objek yang seharusnya hanya menjadi perantara, tetapi malah sebaliknya dimintai pertolongan, bukan kepada Allah.

Punden Mbah Gosang adalah salah satu aspek simbolis yang menunjukkan tempat yang biasa digunakan peziarah berdoa dalam ritual ziarah. Punden Mbah Gosang dapat diartikan sebagai pemisah antara yang sakral dan yang profan atau bersifat keduniawian, seperti yang telah diketahui bahwa punden Mbah Gosang berada di tengah lingkungan pasar yang penuh dengan hal-hal yang bersifat duniawi, sehingga diperlukan adanya sekat untuk menjaga kesakralan ritual ziarah Mbah Gosang. Punden ini dilengkapi dengan beberapa macam alat pelengkap pelaksanaan ritual ziarah, yakni: tempayan kecil berisi air yang dipercaya akan membawa berkah kesembuhan bagi peminumnya; pot dupa yang terbuat dari tanah liat sebagai tempat pembakaran kemenyan serta simbol arah kiblat peziarah dalam berdoa yang tertuju pada pohon asam Mbah Gosang; tungku dari bahan alumuninium sebagai tempat pembakaran kemenyan atau wangi-wangian lainnya; dan 'nasi pethak gondho harum pupusé menyan putih' yang berupa kembang dan kemenyan. Maksudnya 'nasi pethak gondho harum' kalau manusia suka dengan nasi, lain lagi dengan jin yang suka dengan kembang yang mempunyai semerbak bau harum, sedangkan 'pupusé menyan putih' mengandung maksud kemenyan yang dibakar memunculkan asap yang berwarna putih. Perlengkapan media ritual tersebut boleh dibawa ataupun tidak oleh peziarah, hal tersebut tergantung dari rasa dan kemantapan hati peziarah saat melakukan ritual.

Punden Mbah Gosang kerap kali disambangi oleh peziarah, baik itu dari warga lokal Semarang maupun dari luar daerah Semarang. Peziarah yang datang terkadang bisa mencapai 15 orang peziarah per hari, namun tidak jarang pula hanya terdapat satu atau dua orang peziarah saja per hari, dan bahkan pernah kejadian tidak ada peziarah sama sekali dalam satu hari itu. Banyak ataupun sedikitnya peziarah yang datang dalam satu hari tidak dapat dipastikan jumlahnya karena hal tersebut menyangkut hajad dari masing-masing individu yang tidak dapat diprediksi kemunculannya.

Ramai atau sepinya peziarah Mbah Gosang turut dipengaruhi oleh faktor pemilihan hari. Menurut Mbah Wagiman, hari yang disakralkan untuk berziarah Mbah Gosang adalah pada hari Jumat, terutama pada Jumat Kliwon dan malam Selasa Kliwon. banyak peziarah berdatangan untuk berdoa di sana. Hari tersebut dipercaya merupakan hari yang keramat dan sangat disakralkan oleh orang Jawa. Hari lainnya yang sering ramai dengan peziarah adalah hari Minggu atau hari libur sekolah, para pegawai dan anak-anak sekolah pada umumnya yang sibuk beraktivitas pada hari-hari kerja biasanya meluangkan waktunya di hari libur untuk berziarah di Punden Mbah Gosang. Harihari khusus tersebut kini belum tentu ramai dengan peziarah lagi semenjak punden dipugar menjadi bangunan terbuka seperti sekarang ini. Peziarah sekarang tidak dapat diperkirakan kedatangannya pada hari-hari khusus di atas karena bisa saja peziarah malah ramai berdatangan pada hari-hari kerja biasa.

Peziarah yang datang menemui juru kunci terlebih dahulu untuk menyampaikan maksud kedatangannya ziarah ke tempat Mbah Gosang. Kembang yang dibawa peziarah dibuka ikatannya dan ditaruh di depan juru kunci agar nantinya doa-doa yang dipanjatkan dapat tersalurkan ke dalam kembang tersebut. Ritual ziarah dimulai dengan pengucapan salam "assalamu'alaikum" kepada Mbah Gosang sebagai bentuk permintaan ijin ziarah di sana secara lisan, lalu dilanjutkan dengan ketukan tiga kali pada pot kemenyan yang mengisyaratkan simbolisme permintaan izin "kulanuwun". Doa yang dilantunkan juru kunci meliputi serangkaian doa tahlil pendek yang di 
dalamnya terdapat wasilah yang ditujukan kepada nabi, wali-wali Allah, dan termasuk Mbah Gosang sebagai perantara doa kepada Allah SWT, diikuti dengan bacaan surah-surah pendek Alquran, seperti surah al-fatihah, an-naas, al-falaq, dan al-ikhlas tiga kali. Dilanjutkan dengan bacaan zikir berupa kalimah istighfar tiga kali, sholawat tiga kali, dan tahlil tujuh kali.

Setelah pembacaan tahlil, kemudian dilanjutkan dengan penyampaian hajad peziarah kepada Mbah Gosang dengan menggunakan bahasa Jawa halus (bahasa Jawa yang digunakan untuk meninggikan lawan bicara dan merendahkan diri sendiri) sebagai sikap rendah hati. Penggunaan bahasa Jawa krama inggil dalam penyampaian maksud hajad bertujuan untuk menghormati dan menjunjung tinggi nama Mbah Gosang, serta memposisikan diri dengan kerendahan hati untuk memohon pertolongan kepada Mbah Gosang. Nama Mbah Gosang disebutkan beberapa kali dalam ritual tersebut menunjukkan kesungguhan permohonan pertolongan terhadap hajad yang ingin segera dilaksanakan. Setelah pengutaraan hajad, dilanjutkan dengan pembacaan surat al-fatihah sebagai penutup dan pemantapan doa agar doa tersebut bisa segera dikabulkan oleh Allah SWT. Ritual ini kemudian ditutup dengan ketukan tiga kali di atas pot kemenyan yang menyimbolkan tanda pamit dan permintaan restu dari Mbah Gosang terhadap hajad peziarah.

Bagian terakhir yang tidak boleh terlewatkan, juru kunci lalu mengambilkan sebagian kembang yang telah didoakan sebelumnya untuk dibawa pulang peziarah dengan maksud ngalap berkah atau mencari berkah dari Mbah Gosang dan sebagian kembang lagi ditinggalkan sebagai wewangian punden, serta tanda bahwa telah ada peziarah yang datang pada hari itu. Wejangan dan doa diberikan juru kunci kepada peziarah ketika menyerahkan kembang tersebut.

Simbolisme wujud terima kasih peziarah kepada juru kunci karena telah dibantu dalam mendoakan hajadnya, yakni berupa pemberian sejumlah uang seikhlasnya. Sejumlah uang yang diberikan peziarah tersebut adalah berdasarkan keikhlasan hati mereka masing-masing, tidak ada patokan harga yang ditetapkan oleh juru kunci terhadap bantuan yang ia berikan. Hal tersebut terjadi karena pada dasarnya juru kunci memang tidak diperbolehkan meminta uang kepada peziarah. Menurut cerita Mbah Wagiman, dulu di punden Mbah Gosang juga sempat pernah terjadi peristiwa di mana juru kunci meminta uang sebesar Rp.50.000 kepada peziarah nenek-nenek yang berpakaian putih-putih yang mengaku berasal dari daerah Bogor, tetapi karena nenek tersebut tidak membawa uang sehingga nenek tersebut tidak diperbolehkan masuk berziarah. Nenek tersebut kemudian pergi, dan beberapa langkah kemudian tiba-tiba menghilang. Tidak lama kemudian juru kunci tersebut ditemukan meninggal. Cerita lainnya datang dari juru kunci Mbah Gosang yang menjabat sebelum dipegang Mbah Wagiman. Suatu ketika ada tamu yang dimintai uang sebesar Rp.100.000 saat meminta tolong kepada juru kunci untuk dibantu dalam ziarah Mbah Gosang, tapi karena peziarah tersebut hanya membawa uang Rp.50.000, maka dikasihlah uang tersebut kepada juru kunci dengan catatan sisa uangnya akan diberikan setelah ia ziarah kembali menepati ujarnya terhadap Mbah Gosang. Belum sempat digunakan uang tersebut, namun si juru kunci tadi telah ditemukan meninggal di samping pohon asam Mbah Gosang.

Pengalaman mistik juru kunci pendahulu tersebut kemudian dijadikan sebagai pelajaran hidup bagi juru kunci selanjutnya agar tidak bernasib sama tragisnya seperti juru kunci pendahulu mereka tersebut. Pantangan-pantangan dalam ritual Jawa yang sebelumnya hanya dianggap sebagi mitos belaka, nyatanya memiliki kekuatan mistis yang real terjadi, meskipun alasan-asalan kultural tersebut terkadang bersifat abstrak dan susah dinalar dengan akal pikiran manusia. Pemikiran tersebut sesuai dengan yang dikatakan Endraswara (2006), bahwa ihwal ghaib memang berhubungan dengan kekuatan materiil dan spiritual yang sulit dijangkau oleh kebudayaan manusia (occulte) yang biasanya diperoleh melalui laku manusia itu sendiri. 


\subsection{Ritual Suronan}

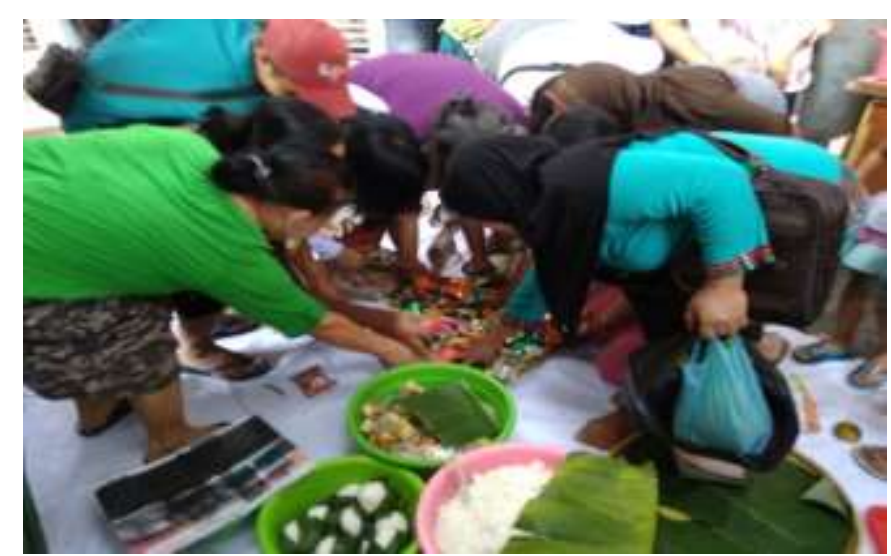

Gambar 3. Masyarakat Saling Berebut Ubarampé pada Ritual Suronan

Penyebutan bulan Suro dalam penanggalan orang Jawa berasal dari kata 'Asyura (bahasa Arab) yang berarti hari ke-10 di bulan Muharam. Bulan Suro atau bulan Muharam merupakan bulan pertama pada penanggalan kalender Islam maupun Jawa. Bulan Suro sendiri dianggap oleh orang Jawa sebagai bulan yang keramat, sakral, dan sekaligus penuh dengan kesialan, musibah, serta bencana. Masyarakat Jawa sangat membatasi aktivitas mereka pada bulan ini untuk menghindari kesialan, nasib buruk, musibah dan lain sebaginya sehingga untuk menghindari hal-hal buruk tersebut, mereka mengadakan upacara ruwatan atau pembersihan pada benda pusaka maupun manusia, ritual ziarah kubur orang suci, ritual sedekah bumi, dan lain sebagainya. Berbagai macam ritual yang dilaksanakan pada bulan Suro tersebut secara universal disebut dengan istilah ritual suronan, yang pada intinya sama yaitu untuk mendoakan keselamatan seseorang dari hal-hal yang buruk, khususnya yang berkaitan dengan hal-hal ghaib.

Ritual suronan yang dilaksanakan di bawah pohon asam Mbah Gosang merupakan bentuk ritual slametan warga Pasar Peterongan, khususnya para pedagang sebagai wujud ritual tolak bala agar terhindar dari segala macam mara bahaya dan sekaligus sebagai wujud syukur kepada Tuhan Yang Esa. Ritual slametan warga Pasar Peterongan ini dipengaruhi oleh kepercayaan terhadap roh halus (Mbah Gosang) yang juga hidup berdampingan bersama mereka di lingkungan pasar, di mana secara tidak langsung dapat mengancam kehidupan mereka apabila tidak dihormati dan sebaliknya dapat memberi dampak positif berupa berkah yang ditularkan apabila dihormati keberadaannya dengan cara dilaksanakannya ritual slametan setiap tanggal 10 Suro atau biasa disebut dengan istilah suronan oleh warga pasar. Kepercayaan terhadap roh halus, khususnya dhayang (roh pelindung) sering diwujudkan dalam bentuk slametan (Endraswara, 2006: 247). Mbah Gosang di sini dapat diibaratkan sebagai roh pelindung (dhayang) bagi masyarakat Peterongan dan sekitarnya, terkhusus bagi warga pasar yang berdekatan langsung dengan Mbah Gosang. Pemilihan tanggal 10 Suro sebagai pelaksanaan ritual suronan ini, menurut Pak Tirmidzi (59 tahun) sebagai kiai pemimpin doa suronan tersebut, yaitu untuk mengenang adat peristiwa dari pembantaian cucu nabi yang bernama Husein bin Ali bin Abi Thalib oleh sesama orang Islam atas dasar kepentingan politik pada waktu itu. Selain mengenang peristiwa pembantaian cucu nabi, tanggal 10 Suro juga dianggap sebagai hari yang baik dan mendatangkan berkah bagi umat Islam mengingat banyak peristiwa kenabian yang terjadi pada tanggal tersebut dan merupakan sesuatu yang sudah menjadi tradisi masyarakat Pasar Peterongan secara turun temurun.

Penyelenggaraan ritual suronan ini merupakan hasil dari gotong royong warga pasar, khususnya para pedagang baik dalam bentuk materi, maupun tenaga untuk menyiapkan 
perlengkapan yang dibutuhkan dalam pelaksanaan ritual. Beberapa hari sebelum pelaksanaan ritual, warga pasar dikoordinir oleh satu orang yang bertugas untuk menggalang bantuan seikhlasnya dari warga pasar, bisa berupa uang, bahan mentah, hasil bumi, jajan pasar dan lainnya yang dibutuhkan sebagai perlengkapan ritual. Setelah bahan-bahan yang diperlukan terkumpul, biasanya pada keesokan hari di tanggal 10 Suro, para pedagang bahu membahu menyiapkan aneka ubarampé ritual di tempat Mbah Wagiman yang tinggal berdekatan dengan punden Mbah Gosang. Tempat Mbah Wagiman dipilih sebagai tempat persiapan ritual karena warga Peterongan masih sangat menghormati Mbah Wagiman sebagai orang yang telah berpengalaman menjadi juru kunci Mbah Gosang dan mengerti betul perlengkapan-perlengkapan yang dibutuhkan dalam pelaksanaan ritual suronan.

Perlengkapan yang dibutuhkan dalam pelaksanaan ritual suronan yaitu berupa, ubarampé atau aneka macam makanan dalam sesajian yang terdiri dari kecok (campuran daging kambing dan rempah), ikan lele, ayam ingkung, nasi golong (nasi kepal yang dibentuk bulat), nasi gudangan (nasi putih biasa yang disajikan bersama sayur-mayur rebus lengkap dengan kelapa parut dan aneka lauk pauk di atasnya), bubur suro, bubur sagu, serta ada minuman yang berupa kopi pahit dan air putih. Mengenai pemaknaan berbagai macam ubarampé tersebut, yaitu sebagai ungkapan rasa kebahagiaan, syukuran warga pasar atas rizki yang dilimpahkan Tuhan dan sekaligus slametan untuk mendoakan Mbah Gosang sebagai leluhur masyarakat dan sesama penghuni Pasar Peterongan Semarang. Simbol ritual bagi Victor Turner tidak hanya berperan sebagai istilah atau abstraksi saja, tetapi harus dilihat juga sebagai sesuatu yang hidup, terlibat dalam proses hidup sosial, kultural dan religius (Turner, 1990: 68).

Perlengkapan lain yang butuhkan dalam ritual suronan ini yakni campuran air kembang dalam sebuah drum besar, dengan maksud sebagai pengharum ketika seseorang mandi atau membasuh dirinya dengan air kembang tersebut. Awal mula benda-benda yang ada di sekitar kita adalah berasal dari partikel air. Air ini mudah sangat mudah merasuk pada setiap benda, begitu juga dengan air kembang mengandung maksud sebagai air berkah yang dapat menyerap keberkahan doa yang dilantunkan oleh Pak Kiai sehingga kalau seseorang mandi atau meminum air kembang tersebut maka keberkahan doa tadi akan dengan mudah terserap ke dalam tubuhnya.

Waktu pelaksanaan ritual suronan dipilih pada sekitar jam 13.00 WIB atau setelah waktu zuhur 10 Suro. Waktu ini dipilih karena merupakan waktu ramainya masyarakat beraktivitas di luar rumah, Berbagai macam sesajian yang telah disiapkan sebelumnya diletakkan di dalam punden untuk didoakan Pak Kiai kampung Peterongan yang berada di belakang pasar. Doa yang dipanjatkan Pak Kiai meliputi pembacaan tahlilan biasa seperti layaknya ritual slametan yang berkembang pada masyarakat Jawa secara umum. Doa "tahlil" secara harfiah berarti berdzikir kepada Allah dengan mengucapkan kalimat tauhid "laa ilaa ha illallah" (tiada Tuhan yang patut disembah kecuali Allah). Tahlil atau yang biasa disebut dengan tahlilan merupakan rangkaian doa yang memuat rangkaian bacaan zikir atau puji-pujian kepada Allah dan ayat-ayat yang bersumber dari Alquran dan Hadis, tak lupa di awal doa tahlil disematkan nama-nama nabi, sahabat nabi, wali Allah, dan orang-orang soleh lainnya, termasuk disebutkan nama Mbah Gosang sebagai perantara doa kepada Allah SWT. Perantara doa melalui tokoh yang dianggap suci ini bertujuan agar keberkahan yang dimiliki mereka dapat menular pada warga penyelenggara ritual dalam bentuk berkah keselamatan dan kesejahteraan hidup mereka. Rangkaian doa selanjutnya disambung dengan membaca surah-surah dari Alquran, mulai dari surah al-fatihah, an-naas, al-falaq, al-ikhlas tiga kali, ayat kursi; lalu dilanjutkan dengan bacaan zikir, seperti kalimah istighfar tujuh kali, sholawat tujuh kali, dan tahlil 33 kali, serta ditutup dengan pembacaan doa tahlil yang dipimpin oleh Pak Kiai. 
Setelah acara tahlilan selesai, satu bungus kembang yang berasal dari dalam punden, kemudian turut dimasukkan ke dalam drum yang sudah berisi campuran air kembang. Simbolisme pemasukan kembang ke dalam drum tersebut sekaligus menjadi tanda keabsahan berkah doa yang ditransfer oleh kembang ke dalam air kembang dan segala ubarampé yang ada di sana.

Pengunjung yang hadir kemudian bisa mengambil air kembang, makanan atau minuman yang telah sah mengandung berkah doa. Makanan tersebut diyakini mengandung berkah doa yang dapat membawa keselamatan bagi si pemakannya. Sama halnya dengan campuran air kembang yang dipercaya akan membawa berkah tersendiri bagi yang meminumnya atau menggunakannya untuk mandi atau untuk mencuci muka (ngalap berkah) sehingga masyarakat yang hadir kemudian saling berebut air kembang dan ubarampé yang ada. Kepercayaan khasiat berkah yang terkandung pada makanan, minuman dan air kembang yang didapat dari ritual suronan tersebut berbeda-beda, tergantung niat penggunaan dari masing-masing individu. Ada beberapa macam penafsiran mengenai keberkahan makanan dan air kembang yang di dapat dari ritual suronan tersebut oleh warga pasar, ada yang diniatkan sebagai sumber keselamatan, keberkahan rizki, penglaris, awet muda, dimudahkan jodohnya, dan lain sebagainya.

Ritual slametan yang digelar oleh warga pasar tersebut diartikan sebagai selamatan agar terhindar dari kekuatan jahat, kekacauan dan sifat-sifat buruk lainnya yang mengancam kehidupan manusia (tolak bala), terutama kejahatan-kejahatan yang mengancam manusia di bulan Suro. Pelaksanaan suronan sendiri secara religius berdampak pada ketenangan jiwa yang dirasakan masyarakat pasar setelah dilaksanakannya ritual. Ritual suronan juga berarti sebagai bentuk pendekatan mereka terhadap Sang Khalik dan sebagai salah satu bentuk penghormatan terhadap nenek moyang yang tanpa disadari ikut andil dalam keberadaan peradaban manusia.

Paham sinkretisme terlalu lembut masuk dalam ajaran Islam, sehingga jarang disadari keberadaannya oleh pengikutnya. Bentuk sinkretis Islam dan budaya Jawa yang tertuang dalam ritual ziarah Mbah Gosang dan ritual suronan yaitu dengan adanya doa-doa yang berdasarkan ajaran Islam dalam setiap pelaksanaan ritus budaya Jawa yang mendapatkan pengaruh dari agama Hindu yang berupa unsur kembang, sesaji, dan kemenyan. Islam sinkretik ini disebut juga dengan Islam Kejawen. Islam Kejawen hadir sebagai religiusitas orang Jawa dalam menjalankan ajaran Islam dan tradisi Jawa. Fenomena Islam Kejawen tidak hanya hadir dalam wilayah pedesaan, namun juga turut mewarnai khasanah budaya perkotaan.

\subsection{Fungsi dan Tujuan Ritual}

Dimensi ekspresif atau impresif manusia, yakni bahwa makna yang tersirat dalam perilaku manusia tergambar dalam cara mereka mengekspresikan diri dalam berinteraksi dengan orang lain yang juga bersifat ekspresif (Goffman, 1956). Interaksi manusia ini tidak hanya berlaku dengan orang lain, melainkan juga dengan lingkungan budaya yang ada di sekitarnya yang dapat memunculkan makna dengan multitafsir.

Melihat fenomena-fenomena supranatural terkait dengan Mbah Gosang seperti yang telah dijelaskan sebelumnya, di sini diperlukan adanya pemikiran logis dan bijaksana dalam melihat fenomena ritual di bawah pohon asam Mbah Gosang karena memang beberapa kasus terkait dengan Mbah Gosang tersebut belum dapat dibuktikan validitasnya secara ilmiah oleh masyarakat. Menurut Peursen (1988), masyarakat ini berada dalam tahap mitis, yaitu sikap manusia yang merasakan berada dalam lingkungan kekuatan-kekuatan ghaib, yakni berupa kekuasaan atas dewa-dewa, roh leluhur, dan sebagainya seperti yang digambarkan dalam mitologi-mitologi bangsa primitif, dan hal ini pun masih dapat dilihat dalam dunia modern seperti sekarang ini. Masyarakat yang meyakini 
mitos-mitos dan kekuatan supranatural yang menyertai Mbah Gosang, secara tidak langsung telah diarahkan oleh keyakinan mereka bahwa terdapat suatu fungsi yang melibatkan hubungan antara manusia dengan daya-daya kekuatan alam. Keberadaan fungsi maupun tujuan diadakannya sebuah ritual di dalam suatu masyarakat terkadang ada tanpa disadari oleh masyarakat tersebut. Berikut merupakan fungsi dan tujuan diadakannya ritual ziarah dan suronan di bawah pohon asam Mbah Gosang.

\subsubsection{Fungsi Ritual}

\section{1) Sebagai Penghormatan terhadap Nenek Moyang}

Penghormatan terhadap nenek moyang terwujud dalam tingkah dan laku masyarakat yang mensakralkan pohon asam besar yang berada di pelataran Pasar Peterongan yang diyakini sebagai tempat keberadaan mendiang Mbah Gosang berada. Menurut kepercayaan masyarakat, Mbah Gosang merupakan manusia pendahulu atau nenek moyang warga Peterongan yang dulunya sangat berjasa bagi kehidupan masyarakat, maka sebagai wujud penghormatan masyarakat terhadap jasajasa Mbah Gosang dilakukan serangkaian ritual keagamaan yang berisi doa-doa yang baik di petilasan Mbah Gosang. Tidak jarang tamu yang datang ke sana ada yang membawa kembang dan kemenyan, yang secara sederhana merupakan sebagai bentuk sedekah terhadap makhluk ghaib untuk menghormati keberadaan mereka.

2) Sebagai Bentuk Pewarisan Budaya

Budaya ada karena diwariskan. Baik masyarakat Peterongan maupun masyarakat lainnya yang sudah mengetahui dan ikut terlibat dalam ritual yang dilaksanakan di bawah pohon asam Mbah Gosang, mendapatkan kebudayaan tersebut sebagai bagian dari kebudayaan mereka adalah didapatkan dengan cara melalui proses belajar dari lingkungannya. Pengetahuan kultural tersebutlah yang kemudian akan meraka ajarkan terhadap anak cicitnya karena pada dasarnya sistem naluri manusia itu akan meniru tingkah laku seperti yang terdapat pada orang-orang terdekatnya.

3) Sebagai Wujud Tirakatan

Tirakatan merupakan bentuk penjawaan dari bahasa Arab thariqah yang berarti "jalan yang dilalui". Tirakat dapat diartikan sebagai laku spiritual yang dijalani oleh seseorang untuk mencapai sesuatu yang diinginkan. Tirakatan dapat dilakukan dalam berbagai macam laku spiritual, seperti mengekang hawa nafsu dengan berpuasa, bertapa di tempat yang sunyi, begadang, ziarah, dan lainnya sesuai masing-masing kepercayaan dan ajaran spiritual yang dianut oleh individu. Banyak masyarakat yang datang ke tempat Mbah Gosang dengan niatan agar hajad yang diinginkan cepat tercapai. Masyarakat tersebut melakukan laku tirakatan dengan cara berziarah di punden Mbah Gosang atau dengan cara memintakan air kembang dan ubarampé pada ritual suronan.

4) Sebagai Pengingat Akan Kematian

Keberadaan alam ghaib, makhluk halus, dan dunia kasap mata lainnya yang ditempati manusia setelah mati diyakini ada dalam ajaran agama Islam. Emosi keagamaan akan muncul saat seseorang menjalankan ritual ziarah Mbah Gosang ataupun suronan, keduanya sama-sama melibatkan kekuatan nenek moyang sebagai perantara doa kepada Allah. Nenek moyang yang tidak lain merupakan manusia pendahulu yang sudah mati seperti nabi, sahabat, wali, dan Mbah Gosang sendiri, mengingatkan peziarah tersebut terhadap kematian sehingga ia akan lebih memperbaiki dirinya menuju kebaikan sebagai persiapan bekal sebelum kematian menghampirinya.

5) Secara Sarana Integrasi Sosial 
Integrasi sosial atau keteraturan sosial merupakan hal yang didamba-dambakan oleh semua orang dalam menjalankan kehidupannya bermasyarakat. Kaitannya dengan pelaksanaan ritual ziarah Mbah Gosang, yaitu dengan adanya peziarah yang datang untuk memenuhi kebutuhan diri atas hajad yang ia ingin wujudkan. Setelah hajad tersebut berhasil dipenuhi sehingga kemudian akan muncul perasaan lega dan bahagia pada diri orang tersebut. Ritual dalam kasus ini berfungsi sebagai sarana yang dapat memunculkan keteraturan sosial dalam diri manusia itu sendiri atau antara manusia dengan manusia lainnya.

\subsubsection{Tujuan Ritual}

Tujuan pelaksanaan ritual ziarah Mbah Gosang maupun suronan pada intinya adalah untuk mendekatkan diri kepada Tuhan yang Maha Esa. Seorang hamba akan melakukan apa saja agar keinginannya segera dikabulkan oleh Tuhan, termasuk berdoa dengan bersungguh-sungguh mendekatkan diri kepada-Nya walaupun harus melalui perantara makhluk ciptaan-Nya yang lain yang dianggap suci. Tata cara mendekatkan diri kepada Tuhan boleh berbeda-beda bentuk pelaksanaanya, namun meskipun begitu Tuhan akan tetap tahu maksud dan tujuan dari tingkah laku hamba-hambanya tersebut. Parsons senantiasa beranggapan bahwa aksi selalu diarahkan pada tujuan, baik sebagai suatu unit maupun proses antara sistem-sistem organismik, kepribadian, sosial, maupun kebudayaan (Parsons, 1986: 62).

Esensi agama Jawa (the religion of Java) adalah pada pemujaan pada nenek moyang atau leluhur yang diwujudkan melalui sikap mistik dan slametan, emang secara lahiriah mereka terlihat seperti memuja terhadap ruh dan kekuatan lain, namun esensinya tetap tertuju kepada Tuhan (Endraswara, 2006). Budaya agama Jawa atau yang sering dikenal dengan Islam Kejawen pada hakikatnya menganggap Tuhan sebagai satu-satunya yang hak untuk disembah dan sebagai sumber anugerah bagi hamba-hambanya, sedangkan roh leluhur atau kekuatan lainnya hanya sebagai perantara (wassilah) yang dapat menghubungkan seorang hamba kepada Tuhan.

\section{Simpulan}

Berdasarkan hasil penelitian yang telah dipaparkan sebelumnya, ritual yang dilakukan di bawah pohon asam Mbah Gosang memiliki dua wujud tradisi budaya yang masih diyakini kesakralannya sampai sekarang, yakni ritual ziarah dan suronan yang sama-sama melibatkan Mbah Gosang sebagai perantara doa atau tawassul kepada Tuhan. Kedua bentuk ritual tersebut memiliki struktur, tata cara, serta pemaknaan tersendiri dalam hal pelaksanaan sesuai dengan kepercayaan masing-masing pelaku ritual. Secara simbolis, ritual ziarah dan suronan dimaksudkan sebagai tradisi turun temurun dan bentuk penghormatan terhadap Mbah Gosang sebagai nenek moyang warga Peterongan yang mempunyai daya linuwih. Diperlukan adanya pandangan yang komprehensif untuk melihat sebuah fenomena budaya yang kompleks agar tidak terjerumus pada penilaian yang keliru seperti yang digadang-gadang masyarakat awam selama ini mengenai pelabelan musyrik terhadap peziarah yang datang ke punden Mbah Gosang.

Umumnya para peziarah memiliki motivasi khusus dalam melakukan ritual ziarah Mbah Gosang di antaranya, yaitu untuk perbaikan ekonomi, mencari kemakmuran hidup berupa perlindungan dari hal ghaib, agar dagangan laris, mencari kesembuhan, serta mencari petunjuk dalam menghadapi masalah kehidupan. Selain itu, ritual yang dilakukan di bawah Mbah Gosang juga memiliki fungsi tersendiri yang secara tidak langsung merupakan bentuk penghormatan 
terhadap nenek moyang, pewarisan budaya, wujud tirakatan, pengingat akan kematian, dan sarana integrasi sosial, sedangkan tujuan ritual tersebut tidak lain adalah untuk mendekatan diri kepada Tuhan yang Maha Esa.

\section{Daftar Pustaka}

Belshaw, Cyril S. 1981. Tukar Menukar Tradisional Dan Pasar Modern. Jakarta: PT Gramedia. Endraswara, Suwardi. 2006. Mistik Kejawen; Sinkretisme, Simbolisme, dan Sufisme dalam Budaya Spiritual Jawa. Yogyakarta: Penerbit Narasi.

Geertz, Clifford. 1992. Kebudayaan dan Agama, (Diterjemahan oleh Francisco Budi Hardiman). Yogyakarta: Kanisius.

Goffman, Erving. 1956. The Presentation of Self in Everyday Life. Edinburg: University of Edinburg Social Sciences Research Center. https://monoskop.org/images/1/19/Goffman_Erving_The_Presentation_of_Self_in_Everyday_ Life.pdf [8 Agustus 2019]

Humaeni, Ayatullah. 2015. Ritual, Kepercayaan Lokal dan Identitas Budaya Masyarakat Ciomas Banten. El Harakah, Vol. 17, No. 2. https://media.neliti.com/media/publications/23804-IDritual-kepercayaan-lokal-dan-identitas-budaya-masyarakat-ciomas-banten.pdf [24 Mei 2019]

Irianto, Agus Maladi. 2015. Interaksionisme Simbolik; Pendekatan Antropologis Merespon Fenomena Keseharian. Semarang: Gigih Pustaka Mandiri.

Koentjaraningrat. 1984. Kebudayaan Mentalitas dan Pembangunan. Jakarta: PT Gramedia. Koentjaraningrat. 1985. Ritus Peralihan di Indonesia. Jakarta: PN Balai Pustaka.

Spradley, James P. 1997. Metode Etnografi, (Diterjemahkan oleh Misbah Zulfa Elizabeth).Yogyakarta: PT. Tiara Wacana Yogya.

Muhammad, Djawahir, (ed.). 1996. Semarang Sepanjang Jalan Kenangan. Semarang: Pemda Dati II Semarang - Dewan Kesenian Jawa Tengah - Aktor Studio Semarang. Noerhadi, Dr. Toeti Heraty. 2013. Aku dalam Budaya; Telaah Metodologi Filsafat Budaya. Jakarta: PT Gramedia Pustaka Utama.

Parsons, Talcott. 1986. Fungsionalisme Imperatif. Jakarta: CV. Rajawali.

Peursen, Cornelis Atonie Van. 1988. Strategi Kebudayaan. Yogyakarta: Kanisius.

Syam, Nur. 2005. Islam Pesisir. Yogyakarta: LkiS Yogyakarta.

Turner, Victor. 1990. Masyarakat Bebas Struktur; Liminalitas dan Komunitas Menurut Victor Turner. Yogyakarta: Kanisius.

Winarsih, Tri (2008), Perkembangan dan Peranan Pasar Peterongan di Semarang terhadap Kehidupan Sosial-Ekonomi Masyarakat di Kelurahan Peterongan dan Sekitarnya Tahun 1978-2001, Skripsi, Universitas Dipongoro. 